originalni

naučni

rad

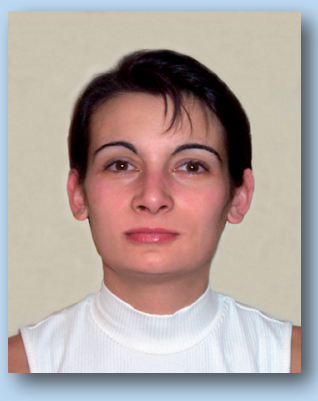

dr Nataša Kožul

Samostalni ekspert i konsultant za investiciono bankarstvo nkozul@gmail.com

Originalna verzija teksta je na engleskom jeziku

\title{
Rezime
}

S obzirom na nedavni dolazak u centar pažnje dužničke krize evrozone i degradiranja rejtinga ne samo duga SAD, već i duga drugih zemalja i mnogih Britanskih velikih bankarskih institucija, ovaj rad ima za cilj da objasni koncept prinosa obveznica, njegove različite mere i jednačinu za formiranje cena obveznica. Prinosi na instrumente tržišta kapitala retko se kotiraju na istoj osnovi, što čini nemogućim direktno poređenje između različitih mogućnosti za investiranje. Neki se dužnički instrumenti kotiraju na diskontnoj osnovi, dok se po kuponskim instrumentima različito obračunava kamata, nude se različite mogućnosti kapitalisanja kamate, učestalost plaćanja po kuponima je različita i različito se postupa sa dospećima na neradni dan. Dalje, pravila koja uređuju dug razlikuju se po zemljama, tržištima i valutama, čineći izračunavanje prinosa i poređenje složenim pitanjem. Otuda se ovde daju neki osnovni koncepti primenljivi na merenje dužničkih instrumenata, sa fokusom na jednačinu obveznica. Pored toga prikazana je jednačina za obveznice izražena $u$ formi anuiteta i iskorišćena za primenu Newton-Raphson algoritma za izvođenje pravog prinosa obveznice.

Ključne reči: prinos obveznice, jednačina obveznice, pravi prinos, NewtonRaphson

JEL: C14, G11, G12 


\section{DERIVING THE BOND PRICING EQUATION}

\section{Summary}

Given the recent focus on Eurozone debt crisis and the credit rating downgrade not only of US debt, but that of other countries and many UK major banking institutions, this paper aims to explain the concept of bond yield, its different measures and bond pricing equation. Yields on capital market instruments are rarely quoted on the same basis, which makes direct comparison between different as investment choices impossible. Some debt instruments are quoted on discount basis, whilst coupon-bearing ones accrue interest differently, offer different compounding opportunities, have different coupon payment frequencies, and manage non-business day maturity dates differently. Moreover, rules governing debt vary across countries, markets and currencies, making yield calculation and comparison a rather complex issue. Thus, some fundamental concepts applicable to debt instrument yield measurement, with focus on bond equation, are presented here. In addition, bond equation expressed in annuity form and used to apply Newton-Raphson algorithm to derive true bond yield is also shown.

Keywords: bond yield, bond equation, true yield, Newton-Raphson

JEL: C14, G11, G12 


\section{Uvod}

Dužničke hartije od vrednosti tipično se prema ročnosti klasifikuju $\mathrm{u}$ instrumente novčanog tržišta sa dospećima do jedne godine i u instrumente tržišta kapitala, sa dospećima do 50 godina. Ti instrumenti se otplaćuju o dospeću, sa povraćajem koji se realizuje u formi redovnih plaćanja (kuponi) ili povećanim iznosom završne otplate. Sa ročnostima do 50 godina i mnogim varijacijama u kotacijama, poređenje prinosa po raznim dužničkim ugovorima nije jednostavno. Pošto su kuponi tipično plativi kvartalno, polugodišnje ili godišnje, instrumenti kraće ročnosti tipično isplaćuju svu kamatu zajedno sa glavnicom o dospeću. Pored toga, neki instrumenti se prodaju na diskontnoj osnovi, tako što se glavnica otplaćuje o dospeću, bez međuplaćanja. Dug koji se prodaje $\mathrm{u}$ različitim zemljama podvrgnut je različitim šemama neradnih i radnih dana a i konvencije o broju dana u godini mogu da se razlikuju. Pored toga, kamata se obračunava različito za različite instrumente, često zavisno od različitih pravila kapitalisanja kamate. Zato je bitno razumeti sve aspekte formiranja cene duga da bi se izračunavali i poredili njihovi prinosi. Sledeći odeljci će prikazati različite mere prinosa, praćene izvođenjem jednačine za obveznice i njenim korišćenjem za iterativno utvrđivanje pravog prinosa obveznice primenom NewtonRaphson algoritma.

\section{Koncept prinosa}

Pojednostavljeno, prinos je povraćaj na investiciju. To je iznos prihoda koji se generiše investiranjem iznosa glavnice na izvestan vremenski period. Uprkos različite terminologije koja se primenjuje na dužničke instrumente, kao i različitih načina na koje se iskazuje prinos, opšta pravila koja se generalno primenjuju jesu sledeća:

1. Kamata koja se plaća odraz je rizičnosti investicije, tj. verovatnoće neizvršenja za držaoca duga.

2. Dugoročniji instrumenti treba da plate višu kamatu od kratkoročnih, jer investitori žele da budu obeštećeni zato što na duži period daju svoja sredstva.

3. U okruženju pozitivnih kamatnih stopa, po instrumentima koji ne plaćaju putem međuvremenih kupona prinosi su niži $u$ poređenju sa onima koji nude redovan prihod, jer je mogućnost za reinvestiranje izgubljena.

Pošto je dugoročniji dug, koji se uobičajeno naziva obveznica, najčešći instrument kojim se trguje, u daljem tekstu se daju neke različite mere prinosa po obveznicama koje mogu da se izvedu iz tržišnih cena.

\section{Tekući prinos}

Mada je vrlo pojednostavljen i ne naročito informativan, tekući prinos je tipično prvo sredstvo za poređenje između različitih ugovora, jer daje odnos između godišnjeg kupona i tekuće cene obaveznica (izraženo kao iznos plativ na 100 USD, ili bilo koje valute, obveznica). Ovde se koristi čista cena obveznice, dok je aktuelan iznos koji bi investitor platio poznat kao prljava cena, koja uključuje iznos kupona naraslog od poslednjeg datuma za kupon do datuma kupovine. Tekući prinos se daje kao

$$
\mathrm{y}_{\mathrm{c}}=\mathrm{C} / \mathrm{P}
$$

gde je $y_{\mathrm{c}}$ tekući prinos, $C$ je kupon (tipično plativ godišnje ili polugodišnje) i $P$ je čista cena obveznice.

Tekući prinos treba da se koristi samo za poređenje kratkoročnih obveznica koje se ne drže do dospeća, jer cene obveznica teže da prikažu fenomen poznat kao približavanje nominalnoj vrednosti, gde se tržišna cena približava iznosu otkupa kako ugovor dospeva. Tako, obveznice kupljene uz premiju (kupovna cena iznad \$100) pretrpeće kapitalne gubitke, dok suprotno važi za obveznice kupljene po diskontu.

\section{Prost prinos do dospeća}

Ova mera uzima u obzir približavanje nominalnoj vrednosti, dok uzima pretpostavku da će ugovor da se drži do dospeća. Izračunava se korišćenjem sledećeg izraza:

$$
y_{\mathrm{s}}=\frac{C+\frac{R-P}{T}}{P}
$$

$\mathrm{y}_{\mathrm{s}}$ je prost prinos do dospeća, $C$ je kupon, $P$ je čista cena obveznice. $R$ je iznos otplate, a 


\section{Introduction}

Debt securities are typically classified by maturity into money markets instruments with maturity of up to one year, and capital markets instruments, with maturities extending up to 50 years. These investments are repaid at maturity, with return realized either in the form of regular payments (coupons), or increased final repayment amount. With maturities extending to 50 years and many variations in the quotations, comparison of yields across different debt contracts is not straightforward. As coupons are typically payable quarterly, semi-annually or annually, shorter-dated instruments typically repay all interest, together with the principal, at maturity. In addition, some instruments are sold on discount basis, whereby principal is repaid at maturity, with no interim payments. Debt sold in different countries is subject to different holiday and workday schedules, and daycount and year conventions may vary. In addition, interest accrues differently for different instruments, often subject to different compounding rules. Thus, understanding all aspects of debt pricing is essential in order to calculate and compare their yields. The following sections will introduce different measures of yield, followed by the derivation of bond equation and its usage to iteratively determine the true bond yield using Newton-Raphson algorithm.

\section{The Concept of Yield}

Put simply, yield is a return on investment. It is the amount of income generated by investing the principal amount over a certain period of time. Despite different terminology applied to debt instruments, as well as different means of expressing yield, the following general rules generally apply:

1. Interest payable is a reflection of riskiness of investment, i.e. the likelihood of default on behalf of the debt holder.

2. Longer date instruments should pay higher interest than shorter-dated ones, as the investors wish to be compensated for locking-in their funds over a longer period.

3. In a positive interest rate environment, yields on instruments that pay no interim coupons are lower compared to those that offer regular income, as reinvestment opportunity is lost.

As longer-maturity debt, most commonly referred to as bond, is the most commonly traded debt instrument, some different measures of bond yield that can be derived from market prices are given below.

\section{Current Yield}

Although very simplistic and not particularly informative, current yield is typically the first means of comparison between different contracts, as it gives the ratio between the annual coupon and the current bond price (expressed as an amount payable for 100 USD, or any other currency, of bond). Here, clean bond price is used, whereas the actual amount an investor would pay is known as dirty price, which incorporates the amount of coupon accrued from the last coupon date to the purchase date. Current yield is thus given by:

$$
\mathrm{y}_{\mathrm{c}}=\mathrm{C} / \mathrm{P}
$$

where $y_{c}$ is the current yield, $C$ is the coupon (typically payable annually or semi-annually) and $P$ is the clean bond price.

Current yield should only be used to compare short-dated bonds that are not held to maturity, as bond prices tend to exhibit a phenomenon known as pull to par, whereby the market price approaches the redemption amount as the contract matures. Thus, bonds bought at premium (purchase price greater than \$100) will suffer capital losses, with the opposite being true for bonds purchased at discount.

\section{Simple Yield to Maturity}

This measure takes into account pull to par, whilst assuming that that contract will be held until maturity. It is calculated using the expression below:

$$
y_{\mathrm{s}}=\frac{C+\frac{R-P}{T}}{P}
$$

$y_{s}$ is the simple yield to maturity, $C$ is the coupon, $P$ is the clean bond price, $R$ is the redemption amount, and $T$ is the duration of the 
$T$ duracija ugovora o obveznici preostala do dospeća, izražena kao odnos između preostalih godina (dana) do dospeća i pune dužine trajanja ugovora o obveznici, merene godinama (danima).

Jasno, gornji izraz ne uzima $u$ obzir dinamiku plaćanja. Međutim, dok tekući prinos podcenjuje stvarni prinos obveznice, jer ne uzima u obzir kapitalne dobiti, prosti prinos do dospeća ga precenjuje (jer kapitalne dobiti raspoređuje ravnomerno do dospeća). Tako, pošto se te mere lako izračunavaju, one daju granice unutar kojih leži pravi prinos, dajući neki uvid u granicu greške sa kojom operiše investitor kada obavlja kupovinu.

U praksi, prinos obveznice do dospeća koristi se za poređenje različitih ugovora. Međutim, pošto se ne može izraziti u zatvorenoj formi datoj za gornje mere, izvodi se iterativno iz jednačine za cene obveznice, koja se razvija u daljem tekstu.

\section{Prinos do dospeća}

Kao što je gore napomenuto, formula za izračunavanje prinosa do dospeća ne može se dati u zatvorenoj formi. Međutim, pošto se iterativno izvodi iz jednačine za cene obveznica, to je najtačnija mera pravog prinosa obveznice, jer ne samo da uzima $\mathrm{u}$ obzir dinamiku kuponskih plaćanja, već i pretpostavlja da se ti kuponi reinvestiraju od njihovog datuma plaćanja do dospeća ugovora. Međutim, da bi se izveo prinos iz cene obveznice kotirane na tržištu, mora da se uzme pretpostavka da su kuponi reinvestirani po prinosu do dospeća (izračunato u vreme kupovine) a ne po važećim tržišnim stopama. Pošto se stope menjaju vremenom, svaki kupon će, praktično, da se reinvestira po različitim stopama, čineći nemogućim da se u vreme nastanka ugovora precizno izračuna stvarni prinos koji će se realizovati.

\section{Druge mere prinosa}

Pošto neće svi investitori držati obveznice do dospeća, često rađeno izračunavanje je prinos tokom perioda držanja, koje ne samo da procenjuje stopu reinvestiranja za sve kupone koji će se primiti i cenu po kojoj će se trgovati obveznicom pre dospeća, već takođe mora da pretpostavi određenu stopu reinvestiranja za sve kupone koji će se izgubiti kada se ugovor proda, kao i cenu kod dospeća.

Drugi često navođeni izraz je prinos do prosečnog trajanja, primenljiv na obveznice sa planom otplate, gde emitent planira da otplati određen procenat nasumično odabranih ugovora tokom trajanja obveznice. Jasno, to uvodi još jedan nivo složenosti, jer je potrebno da se uračuna verovatnoća da konkretan ugovor bude odabran. Najzad, neki ugovori o obveznicama nude opciju da emitent otplati (opozove) obveznicu ranije (opozive obveznice), ili daje investitoru pravo da prekine ugovor na specifičan datum pre dospeća (prodajne obveznice). Ove implicitne opcije znatno komplikuju izračunavanje cene obveznica, jer moraju da obuhvate cene derivatnih hartija od vrednosti. Tako, one tipično čine grubom procenu prinosa na obveznicu do opoziva ili do prodaje. Ipak, prinos do opoziva i prinos do prodaje izrazi su koji se koriste da se opiše realizovani prihod do prestanka ugovora o obveznici pre njegovog dospeća i služe kao gruba mera vrednosti takvih investicija.

\section{Jednačina za obveznice}

Kao što je napomenuto ranije, cene obveznica kotirane na tržištu jesu čiste cene, koje ne uzimaju u obzir kupon koji je narastao od poslednjeg datuma plaćanja kupona. Međutim, kada se u nekom momentu obveznica kupi/proda posle prvog emitovanja, trenutak kupovine je bitan, jer će naredni kupon biti plativ u celosti tekućem držaocu ugovora, čak iako bi je držao samo delić kuponskog perioda. $\mathrm{Na}$ taj način prvobitni držalac obveznice mora da bude obeštećen za gubitak kupona do datuma prodaje/kupovine. Tako, kada se izvode jednačine za cenu obveznice, javljaju se tri pitanja:

1. Izračunavanje naraslog kupona

2. Utvrđivanje stopa reinvestiranja za svaki naredni kupon

3. Tačni vremenski periodi između plaćanja po kuponima (koji se mogu razlikovati zbog vikenda i praznika).

Da bi se izvela opšta formula za utvrđivanje cene obveznice, korisno je početi sa jednostavnijim primerom, gde je ostao samo jedan kupon do dospeća. 
bond contract still left until maturity, expressed as a ratio between the remaining years (days) to maturity, and the full bond contract length, measured in years (days).

Clearly, the expression above does not take into account the timing of the payments. However, whilst the current yield underestimates the actual bond yield, as it takes no account of the capital gains, the simple yield to maturity overestimates it (as it spreads the capital gains evenly until redemption). Thus, as these measures are easy to calculate, they provide the boundaries within which the true yield lies, giving some insight into the margin of error the investor operates with when making a purchase.

In practice, bond yield to maturity is used to compare different contracts. However, as it cannot be expressed in the closed form given for the above measures, it is derived iteratively from the bond price equation, which will be derived later.

\section{Yield to Maturity}

As noted above, the formula for calculation of yield to maturity cannot be given in closed form. However, as it is iteratively derived from the bond pricing equation, this is the most accurate measure of bond true yield, as it not only takes into account the timing of the coupon payments, but also assumes that these coupons are reinvested from their payment date until contract maturity. However, in order to derive yield from market-quoted bond price, the assumption that the coupons are reinvested at yield to maturity (calculated at the time of purchase), rather than at the prevailing market rates, has to be made. As the rates change with time, each coupon will, in practice, be reinvested at different rates, making it impossible to accurately calculate the actual yield that will be realized at the contract inception.

\section{Other Yield Measures}

As not all investors will hold the bond until maturity, a frequently performed calculation is that of holding period yield, which not only estimates the reinvestment rate for all coupons that will be received and the price at which the bond will be traded prior to maturity, it also has to assume a certain reinvestment rate for all the coupons that will be lost once the contract is sold, as well as the price at maturity.

Another frequently quoted term is yield to average life, applicable to bonds with scheduled redemptions, whereby the issuer is planning to redeem a certain percentage of randomly chosen bond contracts over the life of the bond. Clearly, this introduces another level of complexity, as probability of a particular contract being selected needs to be factored in.

Finally, some bond contracts offer an option for either the issuer to redeem (call back) the bond early (callable bonds), or give the investor the right to terminate the contract at specific dates prior to maturity (puttable bonds). These implicit options significantly complicate bond pricing calculations, as they have to incorporate the pricing of derivative securities. Thus, they typically make the estimate of bond yield to call or put rather crude. Nonetheless, yield to call and yield to put are terms used to describe realized income until the bond contract is terminated prior to its maturity and serve as crude measures of the value of such investments.

\section{Bond Equation}

As noted earlier, bond prices quoted in the market are clean prices, which do not take into account the coupon that accrued since the last coupon payment date. However, when the bond is bought/sold at some point after its first issue, the timing of the purchase is essential, as the next coupon will be payable in full to the current contract holder, even though he or she only held it for the fraction of the coupon period. Thus, the original bondholder needs to be compensated for the loss of coupon earned until the sale/purchase date. Thus, when deriving the bond pricing equations, three issues arise:

1. Accrued coupon calculation

2. Determining the reinvestment rates for each subsequent coupon

3. Exact time periods between coupon payments (which may differ due to weekends and holidays)

In order to derive the general bond pricing formula, it is useful to start with a simpler example, whereby only one coupon is left until maturity. 
Ovde će investitor primiti dva gotovinska toka - plaćanje narednog kupona i finalni gotovinski tok (koji uključuje iznos otplate i poslednji kupon). Tako, uz napomenu da tekuća cena bilo koje hartije od vrednosti mora da bude jednaka zbiru očekivanih tokova gotovine, diskontovano natrag do današnjeg dana, tj. sadašnja vrednost svih tekućih plaćanja i budući odlivi moraju da budu jednaki nuli danas $(P V=0)$, možemo navesti:

$$
P=C_{1}+R+C_{2}-A I
$$

gde je

$P$ čista cena obveznice kotirana danas

$C_{1}$ sadašnja vrednost preostalog kupona pre datuma dospeća

R sadašnja vrednost iznosa otplate obveznice

$C_{2}$ sadašnja vrednost kupona plativog na datum dospeća

AI kupon narastao od poslednjeg kuponskog datuma, koji je plativ prethodnom držaocu obveznice

U gornjem izrazu, treba napomenuti da se $A I$ izračunava i plaća na današnji dan i otuda zavisi samo od dela kuponskog perioda za koji je kupon narastao, dok svi nedospeli tokovi gotovine treba da se diskontuju korišćenjem kamatne stope relevantne za taj period. Dalje, pošto iznos otplate i poslednji kupon koincidiraju, treba primeniti istu kamatnu stopu kada se diskontuju oba gotovinska toka.

Drugim rečima,

$$
P=\frac{C}{\left(1+r_{1} \times \frac{t_{p c}}{t_{1}}\right)}+\frac{R+C}{\left(1+r_{1} \times \frac{t_{p c}}{t_{1}}\right)\left(1+r_{2}\right)}-C \times \frac{t_{c p}}{t_{1}}
$$

gde je

$r_{1}$ kamatna stopa za period između današnjeg dana i narednog kupona a

$r_{2}$ kamatna stopa za period između datuma narednog kupona i datuma dospeća

$t_{p c}$ period između datuma kupovine obveznice i narednog kuponskog plaćanja

$t_{1}$ prvi kuponski period

$t_{c p}$ period između poslednjeg kuponskog plaćanja i datuma kupovine obveznice

Jasno, pošto su to varijable koje određuju cenu obveznice kotirane na tržištu, gornji primer može da se proširi na sve nedospele kupone i njihove tačne periode plaćanja.
Međutim, gornji izraz ne prikazuje prinos obveznice, što je ono za šta je investitor zainteresovan. Tako, pri cenama kotiranim na tržištu, investitor može da izvede prinos uzimajući da se svi nedospeli tokovi gotovine diskontuju po prinosu po obveznici. U stvari, to je pristup koji se koristi za izračunavanje stopa svopova, gde su tokovi gotovine koji se diskontuju po stopi za svop izjednačeni svim nedospelim plaćanjima diskontovanim po važećim kamatnim stopama za njihove odgovarajuće periode.

Tako, gornji izraz može da se preradi u sledeći oblik:

$$
P=\frac{C}{(1+y)^{t_{p c}}}+\frac{R+C}{(1+y)^{1+t_{p c}}}-C \times \frac{t_{c p}}{t_{1}}
$$

Ovde, sve varijable imaju isto značenje kao gore, $\mathrm{s}$ tim što $y$ predstavlja prinos obveznice.

Da bi se gornji izraz generalizovao za bilo koji broj nedospelih kupona, jednačina će se preraditi kako sledi:

$$
P=\frac{C}{(1+y)^{t_{p c}}}+\frac{C}{(1+y)^{1+t_{p c}}}+\frac{R}{(1+y)^{1+t_{p c}}}-C \times \frac{t_{c p}}{t_{1}}
$$

ili

$$
P=\sum_{n=1}^{2} \frac{C}{(1+y)^{n-1+t_{p c}}}+\frac{R}{(1+y)^{1+t_{p c}}}-C \times \frac{t_{c p}}{t_{1}}
$$

Uz napomenu da se za dva preostala kuponska plaćanja vrednost otplate diskontuje za $1+t_{p c^{\prime}}$ možemo da generališemo na $N$ nedospelih kupona, gde će diskontni faktor da se da sa $\frac{1}{(1+y)^{N-1+t_{p c}}}$. Prema tome za bilo koji broj nedospelih kupona $N$, gornji izraz se generalizuje na:

$$
P=\sum_{n=1}^{N} \frac{C}{(1+y)^{n-1+t_{p c}}}+\frac{R}{(1+y)^{N-1+t_{p c}}}-C \times \frac{t_{c p}}{t_{1}}
$$

Ili, uzevši u obzir nekonvencionalno plaćanje prvog kupona,

$$
P=\sum_{n=1}^{N-1} \frac{C}{(1+y)^{n+t_{p c}}}+\frac{R}{(1+y)^{N-1+t_{p c}}}+C \times\left[\frac{1}{(1+y)^{t_{p c}}}-\frac{t_{c p}}{t_{1}}\right]
$$

gde se zbir u prvom članu odnosi na sve izuzev prvog kuponskog plaćanja, drugi član je sadašnja vrednost iznosa otplate a poslednji član odnosi se na razliku između PV primljenog punog kuponskog plaćanja i naraslog kupona plativog prethodnom držaocu obveznice. 
Here, the investor will receive two cashflows-the next coupon payment and the final cashflow (which incorporates the redemption amount and the last coupon). Thus, noting that the current price of any security must be equal to the sum of expected future cashflows, discounted back to the present day, i.e. present value of all current payments and future outgoings bust be equal to zero today $(\mathrm{PV}=0)$, we can note:

$$
P=C_{1}+R+C_{2}-A I
$$

where

$P$ is the clean bond price quoted today

$C_{1}$ is the present value of the remaining coupon before maturity date

$R$ is the present value of the bond redemption amount

$C_{2}$ is the present value of the coupon payable at maturity date

$A I$ is the coupon accrued since the last coupon date, which is payable to the previous bondholder

In the expression above, it should be noted that $A I$ is calculated and paid today, and hence depends only on the fraction of the coupon period the coupon accrued for, whereas all outstanding cashflows should be discounted using the interest rate relevant for that period. Moreover, since the payment of the redemption amount and the last coupon coincide, the same interest rate should be applied when discounting both cashflows.

In other words,

$$
P=\frac{C}{\left(1+r_{1} \times \frac{t_{p c}}{t_{1}}\right)}+\frac{R+C}{\left(1+r_{1} \times \frac{t_{p c}}{t_{1}}\right)\left(1+r_{2}\right)}-C \times \frac{t_{c p}}{t_{1}}
$$

where

$r_{1}$ is the interest rate for the period between today and the next coupon and

$r_{2}$ is the interest rate for the period between the next coupon date and the maturity date

$t_{p c}$ is the period between the bond purchase and the next coupon date

$t_{1}$ is the first coupon period

$t_{c p}$ is the period between the last coupon payment and the bond purchase date

Clearly, as these are the variables that determine the bond price quoted in the market, the above example can be extended to all outstanding coupons and their exact payment periods.

However, the expression above does not feature the bond yield, which is what the investor is interested in. Thus, given the marketquoted price, the investor can derive the yield by assuming that all outstanding cashflows are discounted at bond yield. In fact, this is the approach used to calculate swap rates, whereby the cashflows discounted at swap rate are equated by all outstanding payments discounted at prevalent interest rates for their corresponding periods.

Thus, the above expression can be rewritten as follows:

$$
P=\frac{C}{(1+y)^{t_{p c}}}+\frac{R+C}{(1+y)^{1+t_{p c}}}-C \times \frac{t_{c p}}{t_{1}}
$$

Here, all the variables have the same meaning as above, with $y$ representing the bond yield.

In order to generalize the above expression for any number of outstanding coupons, the equation will be rewritten as:

$$
P=\frac{C}{(1+y)^{t_{p c}}}+\frac{C}{(1+y)^{1+t_{p c}}}+\frac{R}{(1+y)^{1+t_{p c}}}-C \times \frac{t_{c p}}{t_{1}}
$$

or

$$
P=\sum_{n=1}^{2} \frac{C}{(1+y)^{n-1+t_{p c}}}+\frac{R}{(1+y)^{1+t_{p c}}}-C \times \frac{t_{c p}}{t_{1}}
$$

Noting that, for two remaining coupon pay ments, the redemption value is discounted by $1+t_{p c^{\prime}}$ we can generalize to $N$ outstanding coupons, whereby the discount factor will be given by $\frac{1}{(1+y)^{N-1+t_{p c}}}$. Thus, for any number of outstanding coupons $N$, the above expression generalizes to:

$$
P=\sum_{n=1}^{N} \frac{C}{(1+y)^{n-1+t_{p c}}}+\frac{R}{(1+y)^{N-1+t_{p c}}}-C \times \frac{t_{c p}}{t_{1}}
$$

Or, by taking into account the irregular first coupon payment,

$$
P=\sum_{n=1}^{N-1} \frac{C}{(1+y)^{n+t_{p c}}}+\frac{R}{(1+y)^{N-1+t_{p c}}}+C \times\left[\frac{1}{(1+y)^{t_{p c}}}-\frac{t_{c p}}{t_{1}}\right]
$$

where the summation in the first term refers to all but first coupon payment, the second term is the present value of the redemption amount and the last term refers to the difference between the $\mathrm{PV}$ of the received full coupon payment and the 


\section{Izračunavanje pravog prinosa}

Pošto gornji izraz uzima redovne kuponske periode, i dalje neće dati tačne vrednosti cene obveznice pri njenom datom prinosu. Međutim, važno je napomenuti da se taj izraz može koristiti da aproksimira prinos obveznice iz poznate tržišne cene metodom pokušaja i greške, pri čemu su različiti prinosi input u gornji izraz a rezultirajuća cena poredi se sa stvarnom cenom obveznice dok se ne postigne zadovoljavajuća preciznost. Pošto bi to zahtevalo mnogo vremena, tipično se najpre izračunaju tekući prinos i prost prinos, jer daju granične vrednosti pravog prinosa, sužavajući na taj način broj potencijalnih vrednosti korišćenih u iteraciji.

Sofisticiraniji pristup, međutim, zahteva da jednačina obveznice bude izražena $u$ formi anuiteta, što se daje u narednom tekstu.

\section{Izvođenje jednačine obveznice $u$ anuitetskoj formi}

Anuitet se odnosi na finansijski proizvod koji nudi tok fiksnih, redovnih plaćanja tokom izvesnog vremenskog perioda bez plaćanja iznosa otplate. Kao takvog, tipično ga koriste penzioni fondovi. Međutim, koncept se može primeniti na određivanje cene obveznica, kako sledi. Uzmimo da se, tokom trajanja anuiteta, izvrši $N$ plaćanja, njihova PV može da se izrazi kao:

$$
A_{N}=\sum_{n=1}^{N} a^{n}
$$

gde je

$$
a=\frac{1}{1+y}
$$

Tako, n-ti podskup gornjih plaćanja može da se napiše kao:

i

$$
A_{n}=a+a^{2}+a^{3}+a^{4}+\ldots+a^{n}
$$

Jasno,

$$
A_{n+1}=a+a^{2}+a^{3}+a^{4}+\ldots+a^{n+1}
$$

$$
A_{n+1}=A_{N}+a^{n+1}
$$

i

$$
a A_{n}=a^{2}+a^{3}+a^{4}+\ldots+a^{n} \text { ili } a A_{n}=A_{n+1}-a
$$

dajući prinos

$$
A_{n+1}=a A_{n}+a \text { ili } A_{n}+a^{n+1}=a A_{n}+a
$$

Tako, $A_{n}$ može da se napiše kao:

$$
A_{n}=\frac{a\left(a^{n}-1\right)}{a-1}
$$

Širenjem ove logike na puni zbir $A_{N^{\prime}}$ originalni izraz može da se napiše kao:

$$
\sum_{n=1}^{N} a^{n}=\frac{a\left(a^{N}-1\right)}{a-1}
$$

Jer

ili

$$
a=\frac{1}{1+y}
$$

$$
y=\frac{a}{1-a}
$$

Anuitet $A_{N}$ može da se izrazi kao:

$$
A_{N}=\frac{1-a^{N}}{y}
$$

Otuda, uključenjem ovog izraza u jednačinu obveznice, cenu obveznice daje:

$$
P=a^{t} c p\left[C \frac{a\left(a^{N-1}-1\right)}{a-1}+R a^{N-1}+C_{1}\right]-A I
$$

gde je

AI narasli kupon

$C_{1}$ neredovni prvi kupon

$a^{t_{c p}}$ diskontni član vezan za period do plaćanja prvog kupona

Uzevši gornji odnos između prinosa po obveznici i anuitetskih članova, jednačina obveznice može da se izrazi kao:

$$
P=a^{t_{c p}}\left[C \frac{\left(a^{N-1}-1\right)}{y}+R a^{N-1}+C_{1}\right]-A I
$$

Mada nova jednačina za obveznice ne izgleda jednostavnija ili lakša za korišćenje od originalne i zaista to nije, njena vrednost je $u$ njenoj primeni kod iterativne evaluacije prinosa po obveznici. U daljem tekstu daje se NewtonRaphson algoritam za izvođenje prinosa do dospeća iz date cene obveznice.

\section{Newton-Raphson algoritam za izvođenje prinosa do dospeća iz tržišne cene obveznice}

Metod Newton-Raphson dobro je poznat numerički metod za procenjivanje korena, ili nula, realno vrednovane funkcije. To je 
accrued coupon payable to the previous bond holder.

\section{True Yield Calculation}

As the expression above assumes regular coupon periods, it will still not provide accurate value of the bond price given its yield. However, it is important to note that this expression can be used to approximate bond yield from the known market price by trial and error, whereby different yields are input into the above expression and the resulting price compared with the actual bond price until satisfactory precision is reached. As this would be very time consuming, typically current yield and simple yield are calculated first, as they would bound the true yield on either side, thus narrowing the range of potential values used in iteration.

A more sophisticated approach, however, requires the bond equation to be expressed in annuity form, which is covered next.

\section{Derivation of Bond Equation in Annuity Form}

Annuity refers to a financial product that offers a stream of fixed, regular payments over a certain time period without repaying a redemption amount. As such, it is typically used by pension funds. However, this concept can be applied to bond pricing, as follows. Assuming that, during the lifetime of an annuity, $N$ payments are made, their PV can be expressed as:

$$
A_{N}=\sum_{n=1}^{N} a^{n}
$$

where

$$
a=\frac{1}{1+y}
$$

Thus, the $n$th subset of the above payments can thus be written as:

and

$$
A_{n}=a+a^{2}+a^{3}+a^{4}+\ldots+a^{n}
$$

Clearly,

$$
A_{n+1}=a+a^{2}+a^{3}+a^{4}+\ldots+a^{n+1}
$$

and

$$
A_{n+1}=A_{N}+a^{n+1}
$$

$$
a A_{n}=a^{2}+a^{3}+a^{4}+\ldots+a^{n} \text { or } a A_{n}=A_{n+1}-a
$$

yielding

$$
A_{n+1}=a A_{n}+a \quad \text { or } A_{n}+a^{n+1}=a A_{n}+a
$$

Thus, $A_{n}$ can be written as:

$$
A_{n}=\frac{a\left(a^{n}-1\right)}{a-1}
$$

By extending this logic to the full sum $A_{N^{\prime}}$ the original expression can be written as:

$$
\sum_{n=1}^{N} a^{n}=\frac{a\left(a^{N}-1\right)}{a-1}
$$

As

$$
a=\frac{1}{1+y}
$$

or

$$
y=\frac{a}{1-a}
$$

The annuity $A_{N}$ can be expressed as:

$$
A_{N}=\frac{1-a^{N}}{y}
$$

Thus, by substituting this expression into the bond equation, the bond price is given by:

$$
P=a^{t} c p\left[C \frac{a\left(a^{N-1}-1\right)}{a-1}+R a^{N-1}+C_{1}\right]-A I
$$

where

AI refers to the accrued coupon

$C_{1}$ is the irregular first coupon

$a^{t_{c p}}$ is the discount term associated with the period until first coupon payment

Noting the above relationship between the bond yield and annuity terms, the bond equation can be expressed as:

$$
P=a^{t_{c p}}\left[C \frac{\left(a^{N-1}-1\right)}{y}+R a^{N-1}+C_{1}\right]-A I
$$

Although the new bond equation does not seem any simpler or easier to use than the original one, and indeed, it is not, its value comes from its application in iterative evaluation of bond yield. Below, the Newton-Raphson algorithm for deriving yield to maturity from given bond price will be given. 
efikasan metod koji se obično brzo približava prihvatljivom nivou tačnosti, pod uslovom da je polazna procena dovoljno bliska nepoznatoj nultoj i da je

$$
f^{\prime}\left(x_{0}\right) \neq 0 .
$$

Za funkciju sa nepoznatom promenljivom, metod Newton-Raphson počinje izračunavanjem izvoda $f^{\prime}(x)$ funkcije $f(x)$ za prvu procenu njegove nule $x_{0}$. Tipično, bolja aproksimacija se dobije koristeci

$$
x_{1}=x_{0}-\frac{f\left(x_{0}\right)}{f^{\prime}\left(x_{0}\right)}
$$

Geometrijski, $x_{1}$ je presek tangente sa funkcijom $f \mathrm{u} f\left(x_{0}\right)$ sa x-osom.

Gornji proces se ponavlja zamenom $x_{0}$ sa $x_{1}$ dok se postigne dovoljno tačna vrednost, tj. primenom izraza:

$$
x_{n+1}=x_{n}-\frac{f\left(x_{n}\right)}{f^{\prime}\left(x_{n}\right)}
$$

Gornja logika može se primeniti na formulu za određivanje cene obveznice $\mathrm{u}$ anuitetskoj formi. Jasno, da bi obveznica dobila tačnu cenu, zbir cene obveznice P i PV nedospelih tokova gotovine mora biti jednak nuli, što se može izraziti kao funkcija $f(a)$, od koje se zahteva koren (nula).

Prema tome,

$$
f(a)=a^{t_{c p}}\left[C \frac{\left(a^{N-1}-1\right)}{y}+R a^{N-1}+C_{1}\right]-A I-P
$$

predstavlja funkciju od koje će koren ili nula dati prinos obveznice do dospeća, čiji se prvi izvod daje u:

$$
\begin{aligned}
f^{\prime}(a) & =a^{t_{c p-1}}\left\{\left[C\left(t_{c p}+\frac{1}{1-a}\right) \frac{a\left(a^{N-1}-1\right)}{a-1}+C_{1} t_{c p}\right]\right. \\
& \left.-a^{N-1}\left[C \frac{a(N-1)}{1-a}-R\left(N+t_{c p}-1\right)\right]\right\}
\end{aligned}
$$

Pošto se odnos između anuitetskog člana i prinosa obveznice daje kao:

$$
a=\frac{1}{1+y}
$$

ili

$$
y=\frac{1}{a}-1
$$

iterativno minimizirajujući gornji izraz za anuitetsku funkciju dok se ne postigne dovoljna tačnost, može se izvesti prinos do dospeća. Inicijalna procena anuiteta $a_{0}$ obično se izračunava korišćenjem kuponske godišnje stope obveznice, podeljene učestalošću plaćanja $(w)$, tj. sa:

$$
a_{0}=\frac{1}{1+C / w}
$$

Međutim, kao u celoj dosadašnjoj diskusiji, gornja izračunavanja podrazumevaju da su svi kuponski periodi (izuzev prvog) podjednaki, $\mathrm{s}$ tim što se zanemaruju razlike koje se mogu javiti zbog vikenda, javnih praznika ili prestupnih godina. Ova pretpostavka obično uvodi zanemarljive greške kod dugoročnijih obveznica, ali mogu znatno uticati na izračun prinosa ako ima samo još nekoliko nedospelih kupona. Otuda, da bi se prevazišlo to pitanje, formula za određivanje cene obveznice mora da obuhvati tačan broj dana za svaki kuponski period. Drugim rečima, u opštoj jednačini za cenu obveznice izražena u anuitetskoj formi

$$
P=a^{t} c p\left[\sum_{n=1}^{N-1} a^{n}+R a^{N-1}+C_{1}\right]-A I
$$

indeks $n$ korišćen gore da bi iskazao različite kuponske periode mora da se zameni tačnim delovima godine u svakom kuponskom periodu. Zato se, u ovom slučaju, neredovno plaćanje prvog kupona može uključiti u zbir jer će biti tačno izračunat dodeljivanjem tačnog broja dana držanja u njegovu vrednost. Tako, preciznija jednačina za obveznicu može se dati kao:

$$
P=C \sum_{n=1}^{N} a^{t_{n}}+R a^{t_{N}}-A I
$$

gde se svaki period $t$ računa kao stvarni broj dana $\mathrm{u}$ tom periodu podeljen sa konvencionalnim brojem dana u godini (360, 365 ili 366).

Najzad, kod primene Newton-Raphson algoritma da bi se izveo pravi prinos iz gornje formule, prvi izvod će se primeniti na funkciju:

$$
f(a)=C \sum_{n=1}^{N} a^{t_{n}}+R a^{t_{N}}-A I-P
$$

i tako će biti data kao:

$$
f^{\prime}(a)=C \sum_{n=1}^{N} t_{n} a^{t_{n-1}}+R t_{N} a^{t_{N-1}}
$$

Iterativna procedura će se kao i ranije primeniti na $a$, gde se pravi prinos izvodi iz njihovog odnosa. 


\section{The Newton-Raphson algorithm for Deriving Yield to Maturity from Bond Market Price}

Newton-Raphson method is a well known numerical method for estimating roots, or zeros, of real-valued function. It is an efficient method that will usually converge fast to acceptable level of accuracy, provided that the initial guess is close enough to the unknown zero, and that

$$
f^{\prime}\left(x_{0}\right) \neq 0 \text {. }
$$

For a function of one unknown variable, Newton-Raphson method starts by calculating the derivative $f^{\prime}(x)$ of the function $f(x)$ for the first estimate of its zero $x_{0}$. Typically, a better approximation is obtained by

$$
x_{1}=x_{0}-\frac{f\left(x_{0}\right)}{f^{\prime}\left(x_{0}\right)}
$$

Geometrically, $x_{1}$ is the intersection of a tangent to the function $f$ at $f\left(x_{0}\right)$ with the $x$-axis.

The above process is repeated by replacing $\mathrm{x}_{0}$ with $\mathrm{x}_{1}$ until a sufficiently accurate value is reached, i.e., by applying the expression:

$$
x_{n+1}=x_{n}-\frac{f\left(x_{n}\right)}{f^{\prime}\left(x_{n}\right)}
$$

The above logic can be applied to the bond pricing formula in the annuity form. Clearly, for the bond to be priced correctly, the sum the bond price $P$ and the PV of outstanding cashflows must be equal to zero, which can be expressed as the function $f(a)$, the root (zero) of which is required.

Thus,

$$
f(a)=a^{t_{c p}}\left[C \frac{\left(a^{N-1}-1\right)}{y}+R a^{N-1}+C_{1}\right]-A I-P
$$

is the function the root of which or zero will yield the bond yield to maturity. its first derivative is given by:

$$
\begin{aligned}
f^{\prime}(a) & =a^{t_{c p-1}}\left\{\left[C\left(t_{c p}+\frac{1}{1-a}\right) \frac{a\left(a^{N-1}-1\right)}{a-1}+C_{1} t_{c p}\right]\right. \\
& \left.-a^{N-1}\left[C \frac{a(N-1)}{1-a}-R\left(N+t_{c p}-1\right)\right]\right\}
\end{aligned}
$$

As the relationship between annuity term and bond yield is given by:

$$
a=\frac{1}{1+y}
$$

or

$$
y=\frac{1}{a}-1
$$

by iteratively minimizing the above expression for annuity function until sufficient accuracy is reached, the yield to maturity can be derived. The initial annuity estimate $a_{0}$ is usually calculated using the bond annual coupon rate, divided by payment frequency $(w)$, i.e. by:

$$
a_{0}=\frac{1}{1+C / w}
$$

However, as in all the discussions so far, the above calculations assume that all coupon periods (with the exception of the first one) are equal, the differences that may arise due to weekends, public holidays or leap years are ignored. This assumption usually introduces negligible errors for longer-dated bonds, but may affect yield calculation significantly if only a few coupons are still outstanding. Thus, to overcome this issue, the bond pricing formula must incorporate exact daycounts for each coupon period. In other words, in the general bond pricing equation expressed in annuity form:

$$
P=a^{t} c p\left[\sum_{n=1}^{N-1} a^{n}+R a^{N-1}+C_{1}\right]-A I
$$

the index $n$ used above to indicate different coupon periods must be replaced by exact fractions of a year in each coupon period. Thus, in this case, the odd initial coupon payment can be incorporated into the sum, as it will be correctly calculated by apportioning the correct days of holding to its value. Thus, the more precise bond equation can be given as:

$$
P=C \sum_{n=1}^{N} a^{t_{n}}+R a^{t_{N}}-A I
$$

where each period $t$ is calculated as the actual number of days in that period divided by the year convention (360. 365, or 366).

Finally, when applying Newton-Raphson algorithm to derive true yield from the above formula, the first derivative will apply to the function:

$$
f(a)=C \sum_{n=1}^{N} a^{t_{n}}+R a^{t_{N}}-A I-P
$$

and will, thus, be given by: 


\section{Zaključak}

Sa toliko mnogo obveznica na tržištu, kotiranih u različitim valutama, na različite periode držanja, ili na diskontnoj osnovi, teško je porediti različite proizvode $\mathrm{u}$ smislu njihovog povraćaja na investiciju. Dalje, kod kuponskih obveznica kamata narasta različito, one nude različite mogućnosti kapitalisanja, imaju različitu učestalost kuponskog plaćanja i na različit način upravljaju datumima dospeća na neradni dan. Ta tržišna pitanja dalje se osložavaju činjenicom da, za razliku od većine finansijskih proizvoda čija cena može jednostavno da se odredi uzimajući da investitor nikad neće platiti više od zbira diskontovanih budućih tokova gotovine, obveznice karakteriše kretanje prema nominalnoj vrednosti, kod koje se tržišna cena neminovno približava otplatnoj vrednosti sa dospevanjem ugovora, što je teško inkorporisati u matematičke formule. Mada izračunavanje prinosa obveznica i poređenje između različitih ugovora predstavlja prilično kompleksno pitanje, ovaj rad je prikazao neke uobičajene forme izračunavanja prinosa 'na prvi pogled', što može biti od koristi kada se porede mnoge kratkoročne obveznice, kao i dobra 'prva procena' kada se pokušava ustanoviti stvarni prinos obveznice. Dok tekući prinos jednostavno daje odnos kupona prema ceni obveznice i time podcenjuje stvarni prinos, prost prinos uključuje sve nedospele tokove gotovine. Međutim, pošto ne uzima u obzir dinamiku plaćanja, on precenjuje stvarni prinos, pružajući na taj način gornju granicu. Te dve vrednosti mogu da se koriste za iterativno izvođenje pravog prinosa do dospeća iz cena kotiranih na tržištu. Međutim, ovde se prikazuje sofisticiraniji metod, kojim se primenom koncepta anuiteta na utvrđivanje cene obveznica, koristi Newton-Raphson algoritam za izvođenje pravog prinosa obveznice. Na tržištu fokusiranom na dug različitih zemalja, vlada i velikih korporacija, to će biti vrlo koristan alat za evaluiranje vrednosti potencijalnih investicija.

\section{Literatura / References}

1. Hamming, R. W. (1973) Numerical Methods for Scientists and Engineers ( $2^{\text {nd }}$ ed.), Dover Publications, New York.

2. Kožul, N. (2014) Bond yield curve construction (Konstruisanje krive prinosa obveznice), Bankarstvo 43 (2): 36-47

3. Steiner, R. (1999) Mastering Financial Calculations, Pearson Education, Harlow.

4. Stigum, M. and Robinson F. L. (1996) Money Market \& Bond Calculations, Irwin Times Mirror Higher Education Group, New York. 


$$
f^{\prime}(a)=C \sum_{n=1}^{N} t_{n} a^{t_{n-1}}+R t_{N} a^{t_{N-1}}
$$

The iterative procedure will, as before, be applied to $a$, whereby the true yield will be derived from their relationship.

\section{Conclusion}

With so many bonds in the market, quoted in different currencies, for different holding periods, or on discount basis, it is hard to compare different products in terms of their return on investment. Moreover, couponbearing bonds accrue interest differently, offer different compounding opportunities, have different coupon payment frequencies, and manage non-business day maturity dates differently. Those market-related issues are further compounded by the fact that, unlike most financial products that can simply be priced assuming that an investor will never pay more than the sum of discounted future cashflows, bonds are characterized by the pull to par feature, whereby the market price inevitably converges to the redemption value as the contract matures, which is hard to incorporate into mathematical formulae. Although bond yield calculation and comparison between different contracts is a rather complex issue, this paper presented some common forms of calculating yield 'at glance', which may be useful when comparing many short-dated bonds, as well as serve as a good 'first guess' when trying to establish the actual bond yield. While current yield simply gives ratio of coupon to the bond price and thus underestimates the actual yield, the simple yield incorporates all outstanding cashflows. However, as it does not take the timing of payments into account, it overestimates the actual yield, thus providing its upper boundary. These two values can be used to iteratively derive true yield to maturity from the market-quoted price. However, here, a more sophisticated method is shown, whereby, by applying the concept of annuity to bond pricing, Newton-Raphson algorithm was used to derive the true bond yield. In the market focused on debt of different countries, governments and large corporates, this will be very useful tool to evaluate the value of potential investments. 